\section{Miguel Jörg: 0 adeus ao último pioneiro da doença de Chagas}

A crônica é às vezes fria e imprecisa, sobretudo quando menciona que Miguel Jörg faleceu no dia 15 de novembro de 2002, em parte da manhã.

Infelizmente, nos deixou o último grande chagologo dos fundadores e iniciadores das pesquisas da doença de Chagas na Argentina.

Faleceu aos 93 anos, prostrado na cama mas, lúcido como nunca passou de um sonho a outro, como para demonstrar que de lá do mundo celestial poderia seguir guiando-nos.

Miguel Jörg foi um dos notáveis, não só pelo aporte médico e científico mas, também, pelos seus ensinamentos humanísticos.

Provavelmente, a maioria dos médicos dedicados ao estudo da doença de Chagas conheceram ou, pelos menos, ouviram falar dele, ligado ao Salvador Mazza, mas dado que muita gente jovem pouco conhece dele, quero enviar estas palavras que nasceram ao contemplá-lo no seu último estado comatoso, ao lado da sua cama e com toda a dor que se sente ao perder o Maestro e Amigo.

Miguel Jörg nasceu no dia 27 de julho de 1909, em Ingeniero White, porto de Bahia Blanca no sul argentino. Filho único de uma família de imigrantes alemães, dedicou-se desde sua infância ao estudo, recebendo uma Medalha de Ouro ao término de seus estudos primários na Escola J.M. Estrada de Buenos Aires (1922) e depois como melhor aluno na escola secundária do Colégio Domingo F. Sarmiento (1926);

Como destacado estudante de medicina, em 1930, o Prof. José Arce, Diretor do Instituo de Clínica Cirúrgica da Universidade de Buenos Aires, incorporou-o como assistente técnico do laboratório de análises biológicas dessa Instituição.

No mesmo ano, num breve encontro, em Montevidéu, durante o Congresso Internacional de Biologia conheceu o Dr. Salvador Mazza, que já tinha instalado a Missão de Estudos de Patologia Regional Argentina (MEPRA), em Jujuy, com a finalidade de pesquisar as doenças endêmicas argentinas, reencontrando-se um ano depois em Buenos Aires, no laboratório do Dr. Flavio Niño. Mazza precisava de um colaborador para a MEPRA e viu que o Jörg poderia realizar muitas tarefas necessárias no seu laboratório. Assim, no dia $1^{\circ}$ de dezembro de 1932, Miguel Jörg foi contratado como assistente extraordinário para trabalhos histopatológicos especiais na MEPRA, na cidade de Jujuy. Desta forma, se juntou, desde 1946, a Salvador Mazza para não se separar até a morte. Como dizia Jörg "Quando Mazza me pescou eu já nadava no lago dele".

A pesquisa marcaria seu rumo, sobretudo durante 14 anos vitais da sua vida, desde 1932 até 1946, época em que foi o principal colaborador de Salvador Mazza.

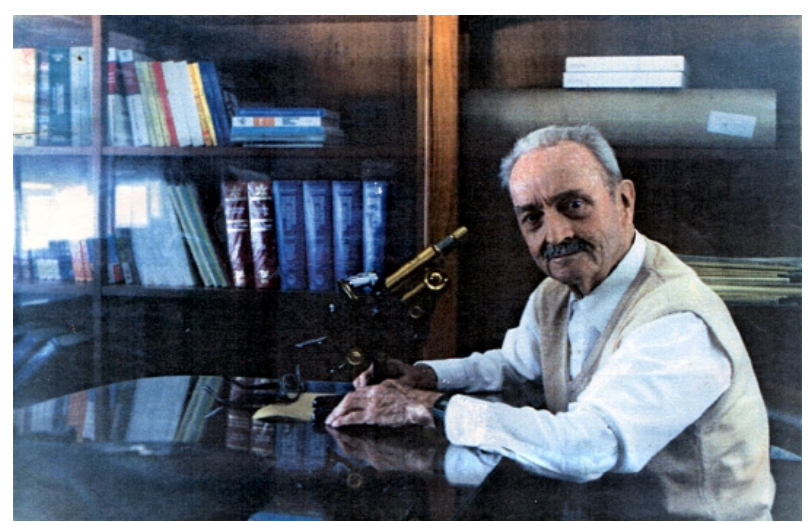

Dr. Miguel Jörg

Junto a Salvador Mazza, e com o respaldo da MEPRA, praticamente não ficou nenhuma doença endêmica, na Artgentina, sem pesquisar, como a malária, o calazar, a leishmaniose. Mas, foi a doença de Chagas a que forjou seu destino científico, já que Mazza e Jörg foram os redescobridores dos alcances epidemiológicos, clínicos, cardiológicos e anatomopatológicos da doença de Chagas, com 1.400 casos para comprovar que A DOENÇA DE CHAGAS EXISTE, realizando 137 necropsias, a maioria em campanha, ranchos miseráveis, sob a luz de um lampião com uma luva vulcanizada e colocando em álcool as peças tiradas, já que não dispunham de formol, dentro de um balde improvisado.

Porém, não se limitaram à MEPRA e incorporaram o vagão sanitário E-600, que era levado pelo trem de carga desde Jujuy aos mais diversos lugares do país. Como verdadeiros aventureiros da ciência, Mazza e Jörg viajaram aos lugares mais distantes e inóspitos a fim de pesquisar, encontrar e confirmar aquilo que eles suspeitavam seria útil na medicina e na ciência. Basta repassar seus anedotários para perceber a epopéia aventureira em favor do avanço da ciência, onde se misturaram com as tribos indígenas, faziamse amigos dos bruxos e convenciam aos autóctones que se deixassem extrair sangue. Viajavam até em aviões que perdiam óleo em pleno vôo, e o co-piloto tinha que agregar o aditivo aferrado à porta e pisando na asa do avião.

Durante suas viagens por todo o país, a fim de descobrir e provar a importância de nossas doenças endêmicas, em especial da doença de Chagas, foram cavalgando, inclusive, montados em pêlo numa mula e muitas vezes caminhando no meio do mato ou entre os cardos, alimentando-se durante vários dias somente com mate e biscoitos. Em algumas ocasiões, ficaram abandonados no meio de zonas áridas e despovoadas, habitando o vagão E-600, esperando outro trem que os levasse de volta à cidade.

Quando Mazza morreu em 1946, Jörg ficou praticamente sem cargo oficial. Como seu Mestre, não era de adular a funcionários e políticos de plantão, 
nem freqüentava os gabinetes dos poderosos. A falta de trabalhos em nada diminuiu suas inquietudes de pesquisador. Continuou seu trabalho sozinho e sem apoio econômico, conseguiu um subsidio mínimo de entidades estrangeiras.

Conheci Miguel Jörg trabalhando como assessor científico no Centro Médico de Mal Del Plata, como ele mesmo dizia "retirado". Uns 15 anos atrás, recebi uma carta de elogios sobre o livro "Miocardiopatia chagásica crónica, un enfoque para el clínico general" que havíamos editado em parceria com Club de Estúdio em 1986. Pouco tempo depois, Ihe fiz uma visita em Mar Del Plata. Desde então, não nos separamos, e o considero Meu Pai Científico e verdadeiro exemplo de como deve ser um médico e um pesquisador. Foi colaborador geral do livro "Enfermedad de Chagas", editado por Mosby-Doyma em 1994.

Tive, também, o prazer de participar de algumas de suas viagens, especialmente a um Congresso Científico em Sierra de la Ventana, onde foi meu companheiro de quarto. Poucas vezes me diverti tanto como quando contava suas anedotas e o espírito jovial que irradiava em todo momento.

É que ele havia inventado uma palavra, a "gadejonencia" ou seja, a vontade de brincar, da alegria que significa viver. Havia aprendido que a pesquisa, a ciência e a medicina são por demais importantes para que a gente se "vista com o fraque da arrogância". Como diziam Albert Einstein e Bertrand Russel, a alegria e o humor deviam marcar o rumo de toda pesquisa científica.
Miguel Jörg era muito mais ainda, já que pertenceu a uma geração que não voltaremos a ver, daqueles homens que não se entregam às adversidades, que não renunciam aos seus princípios, que não se vendem, que não compactuam nem com o poder, nem com mafiosos, que não roubam, que brigam pelo que é nosso, pelas nossas doenças regionais, ainda quando isto signifique viver economicamente de forma muito austera e morrer na pobreza, de forma muito modesta.

O Mestre Jörg, na Argentina, foi Cidadão ilustre de três cidades em que viveu: Bahia Blanca, Vicente López e Mal Del Plata, mas, como disse José Ingenieros foi Cidadão do Mundo, porque tudo Ihe preocupava e tudo Ihe comovia.

Como legado científico nos deixou centenas de trabalhos de pesquisa e publicações, de todo tipo de doenças endêmicas, especialmente da época em que trabalhou na MEPRA, que seria impossível detalhar nesta crônica.

Sinto um grande vazio que jamais poderei preencher. Repasso as folhas do último Manual de Chagas que fizemos juntos e as cartas com as correções vêm na minha mente.

Miguel Jörg, o homem, já não está, mas nascerá o mito do último grande idealista de nossas doenças endêmicas que queria uma Argentina melhor. Este talvez seja seu maior legado. Tomemo-lo e lutemos por outra Argentina e por outra América Latina.

Há tanto por fazer que apenas se tem tempo para chorar.

Obrigado Miguel, por tudo o que aprendi ao seu lado. Seu discípulo de sempre.

\section{Ruben Storino}

Coordenador do Consultório de Chagas Fundação Favaloro-Buenos Aires 